\author{
A N N A L E S \\ UNIVERSITATIS MARIAE CURIE-SKŁODOWSKA \\ LUBLIN - POLONIA \\ VOL. XXIV, 2 \\ SECTIO K
}

2017

Reviews. Reports

Recenzje. Sprawozdania

\title{
Ada Dyndo, Recenzja: Chitralekha Zutshi, Languages of Belonging. Islam, Regional Identity and the Making of Kashmir, Permanent Black, New Delhi 2015, ss. 359.
}

Badania nad Kaszmirem są prowadzone przede wszystkim w ramach studiów nad konfliktami oraz w zakresie stosunków międzynarodowych, obejmujących relacje indyjsko-pakistańskie. Praca prezentująca inną perspektywę badawczą dotyczącą tego regionu zasługuje na szczególną uwagę. Do takich należy książka autorstwa Chitralekha Zutshi zatytułowana Languages of Belonging. Islam, Regional Identity and the Making of Kashmir. Jest to jedna $\mathrm{z}$ niewielu publikacji książkowych, w których autor nie skupia się wyłącznie na współczesnym konflikcie w tym rejonie i jego przyczynach sięgających wydarzeń związanych z podziałem Indii Brytyjskich w 1947 roku, ale szuka źródeł kultury politycznej Kaszmiru w okresie przedkolonialnym. W Languages of Belonging... C. Zutshi analizuje złożoną sytuację społeczno-polityczną tego regionu z perspektywy historycznej i kulturowej, która kształtowała przez wieki zmieniającą się tożsamość Kaszmirczyków. Koncentruje się na analizie „społecznego kontekstu, społecznego otoczenia systemu politycznego" [Garlicki, Noga-Bogomilski 2004: 60], czyli na kulturze politycznej Kaszmiru.

Dyskurs nad kaszmirską tożsamością i kulturą polityczną autorka umiejscawia w kontekście historycznych wydarzeń w Kaszmirze od połowy XVIII wieku. Chitralekha Zutshi odwołała się w swojej analizie do koncepcji longue durée, 'długiego trwania'. Jest to pogląd sformułowany przez Fernanda Braudela, według którego znaczące przemiany historyczne i cywilizacyjne dokonują się w długiej perspektywie czasowej, a nie w wyniku krótkich wydarzeń politycznych. Zastosowanie takiej techniki wydaje się odpowiednie do analizy kultury politycznej, ponieważ jak trafnie zauważył Edmund Wnuk-Lipiński, kultura polityczna to „formowanie przez tradycję życia politycznego określonej wspólnoty, która wynika bezpośrednio z realnej historii politycznej, albo zmitologizowanych przekazów międzygeneracyjnych budowanych na kanwie selektywnie traktowanej historii politycznej wspólnoty" [Wnuk-Lipiński 2008: 163-164]. Autorka zdecydowała się w swojej pracy na zastosowanie perspektywy historycznej, ponieważ, jak sama przyznaje: „Głęboko wierzę, że Kaszmir jest czymś więcej niż 
tylko sporem o terytorium. Musimy spojrzeć na przeszłość, żeby być zdolnym do wydostania się z przeszłości" [Zutshi 2015: 15].

Chitralekha Zutshi z wykształcenia jest historykiem. Urodziła się w Indiach, ale wykształcenie wyższe odebrała w Stanach Zjednoczonych Ameryki. Doktorat w zakresie historii Azji Południowej uzyskała na Tufts University. Obecnie wykłada w College of William and Mary w Wirginii. Jej zainteresowania badawcze koncentrują się wokół zagadnień związanych z tożsamością i ruchami narodowymi, historią i kulturą Kaszmiru. Publikowała swoje artykuły między innymi w: „The Journal of Asian Studies”, „Modern Asian Studies”, „The Indian Economic and Social History Review”, „Economic and Political Weekly”. Jest autorką dwóch książek: Kashmir's Contested Pasts: Narratives, Sacred Geographies, and the Historical Imagination wydanej przez Oxford University Press w 2014 roku i wcześniejszej, z 2003 roku, Languages of Belonging. Islam, Regional Identity and the Making of Kashmir.

Languages of Belonging. Islam, Regional Identity and the Making of Kashmir jest pierwsza książką Chitralekhy Zutshi. Praca opiera się na materiałach źródłowych zarówno historycznych, jak i literackich. C. Zutshi wykonała ogromną pracę nad źródłami, sięgając bezpośrednio do licznych manuskryptów pisanych po persku i po kaszmirsku, dokumentów i raportów rządowych zgromadzonych w archiwach w Dżammu, Śrinagarze, Delhi i Londynie. Autorka wykorzystała bardzo liczne publikacje autorów indyjskich i zachodnich poświęcone analizowanemu regionowi.

Mocną stroną książki jest wykorzystanie w analizie perspektywy kulturowej. Autorka bardzo dobrze zna kulturę omawianego regionu. Sięgnęła do tekstów poetów z Kaszmiru pisanych w języku perskim (perski przez bardzo długi okres był językiem administracji oraz językiem dworu) i w języku kaszmirskim, aby zilustrować przeobrażenia, jakie dokonały się w świadomości politycznej Kaszmirczyków. Dzięki wykorzystaniu perspektywy kulturowej możliwe jest uzyskanie pełniejszego obrazu kultury politycznej Kaszmiru i zmian zachodzących w tożsamości Kaszmirczyków na przestrzeni wieków.

Książka C. Zutshi składa się z sześciu rozdziałów i podsumowania, poprzedzonych słowniczkiem i wstępem. Rozdziały są ułożone chronologicznie i tematycznie. Autorka analizuje rozwój kultury politycznej regionu w czasach przedkolonialnych, od połowy XVIII wieku do ostatnich lat XIX wieku, w czasach rządów brytyjskich na półwyspie indyjskim oraz zarysowuje zmiany w 1947 roku. Koncentruje się na koncepcji Kaszmiru jako ojczyzny, mulk, z którą Kaszmirczyków łączą przede wszystkim więzi terytorialne (regional belongings). Jak przyznała autorka, więzi religijne w tym czasie miały mniejsze znaczenie. Najważniejsze było zbudowanie silnej wspólnoty w opozycji do panujących w regionie obcych władców [Zutshi 2015: 16].

Autorka zwróciła uwagę na rolę, jaką odegrali Brytyjczycy w czasach kolonialnych w zmianie struktury społecznej w regionie i tworzeniu się klas w Kotlinie Kaszmirskiej. To właśnie za czasów rządów brytyjskich Kaszmir stał się częścią stworzonego przez nich księstwa (princelystate) Dżammu i Kaszmiru, nad którym władzę przyznano hinduskiej dynastii Dogrów. Rządy dynastii Dogrów (1846-1947) w Kaszmirze przyczyniły się do pogłębiania różnic w poziomie życia między muzułmanami a hindusami. Wyznający islam mieszkańcy, chociaż stanowili zdecydowaną większość na terenach księstwa Dżammu i Kaszmiru, nie zajmowali stanowisk urzędniczych, w większości byli gorzej wykształceni i stanowili ludność ubogą. Byli dyskryminowani, mieli ograniczone prawa oraz utrudniony dostęp do pracy i edukacji. Tradycyjnie to pandici, czyli wyznawcy hinduizmu należący do najwyższej kasty, byli lepiej wykształceni, znali perski i sanskryt, dzięki czemu posiadali odpowiednie umiejętności do pracy w administracji. Z powodu nierówności społecznych w czasie rządów dynastii Dogrów dochodziło do wielu bun- 
tów ludności muzułmańskiej, skierowanych przeciwko hinduskim władcom. Najpoważniejsze z nich wybuchały w 1931 roku, kiedy chłopi zaprotestowali przeciwko nałożonym na nich zbyt wysokim podatkom. C. Zutshi zauważyła, że nasilający się konflikt między muzułmanami a hindusami był uwarunkowany przyczynami ekonomicznymi i wynikał przede wszystkim z walki o dostęp do pracy [Zutshi 2015: 233]. Dodatkową rolę odegrały także działania Brytyjczyków, którzy podsycali konflikty komunalistyczne, aby uzyskać większą kontrolę w regionie. Jan Kieniewicz pisał, że Brytyjczycy bezpośrednio wpłynęli na administrację i strukturę społeczną w regionie. Wykorzystywali także protesty muzułmańskich chłopów i napięcia na tle religijnym do osłabienia działań niepodległościowych Indyjskiego Kongresu Narodowego [Kieniewicz 1980: 744]. W opozycji do hinduskich władców muzułmańscy Kaszmirczycy zaczęli coraz mocniej jednoczyć się w ramach wspólnoty religijnej w proteście przeciwko ich marginalizacji i uciskowi.

Chitralekha Zutshi poddała krytyce często wykorzystywane przed badaczy i polityków indyjskich definiowanie historii Kaszmiru i kulturowej tożsamości Kaszmirczyków wyłącznie w kontekście koncepcji określanej terminem „kaszmirijat”. Jest to czternastowieczna idea kaszmirskości, która początkowo zakładała synkretyzm religijno-kulturowy w Kaszmirze, w którym różne grupy religijne i społeczne żyły obok siebie w pokoju. W XX wieku koncepcja nabrała wymiaru politycznego i była wykorzystywana przez nacjonalistycznych przywódców politycznych do zjednoczenia Kaszmirczyków, zarówno muzułmanów, jak i hindusów i stworzenia jednego, wspólnego obrazu regionu przed panowaniem dynastii Dogrów jako „kotliny szczęśliwości”. Zarówno indyjskim badaczom, jak i nacjonalistycznym historykom z Kaszmiru zarzuciła postrzeganie przeszłości Kaszmiru przed rządami obcych władców przez „różowe okulary, przez które Kaszmir wydaje się być wyjątkowym regionem, w którym [różne] religijne społeczności żyły w harmonii [...] aż do interwencji z zewnątrz" [Zutshi 2015: 2]. Kwestionuje ideę kaszmirijatu rozumianą jako jednolitą wizję przeszłości Kaszmiru jako regionu wolnego od wewnętrznych konfliktów, różnic religijnych, kastowych, klasowych, regionalnych, językowych i etnicznych. C. Zutshi dokonała polemiki ze zbyt powierzchownym rozumieniem tego pojęcia, co w konsekwencji prowadzi do dużych uproszczeń w interpretacji tożsamości Kaszmirczyków. Autorka zauważyła, że kaszmirska tożsamość znacznie wykracza poza taką interpretację, jest pojęciem znacznie bardziej złożonym, co bardzo dobrze wykazała w swojej pracy. Dla autorki kaszmirskość była i jest szeregiem zmieniających się tożsamości, które tworzyły się pod wpływem różnego rodzaju przynależności (autorka użyła terminu belonging), zwłaszcza tych o charakterze religijnym i narodowym/etnicznym. W języku polskim można je określić terminem ,więzi”, który funkcjonuje w języku naukowym i trafnie oddaje sens społecznych powiązań i zależności wpływających na kulturę polityczną regionu ${ }^{1}$.

W kontekście badań nad Kaszmirem książka Chitralekhy Zutshi jest jedną z ważniejszych pozycji, która w dogłębny i innowacyjny sposób analizuje kulturę polityczną regionu przez wskazanie zmian zachodzących w tożsamości Kaszmirczyków. Autorka zidentyfikowała różne formy przynależności społecznej (belongings), które są budowane na bazie religii, wspólnoty regionalnej, identyfikacji narodowej/etnicznej. Wskazała na zmiany w ich rozumieniu i interpretacji oraz ich znaczeń na przestrzeni lat, tj. przed okresem panowania Brytyjczyków w Indiach, pod wpływem działań brytyjskich, a także krótko opisała najważniejsze zmiany tuż po 1947 roku.

\footnotetext{
1 Por. Załęski [2011]; Syliwoniuk [2016].
} 
Książka Chitralekhy Zutshi jest bardzo ważną pozycją nie tylko dla tych, których interesuje Kaszmir, ale także tych, którzy chcieliby przyjrzeć się, na przykładzie tego regionu, procesom kształtowania się tożsamości politycznej w Azji Południowej, zwłaszcza w kontekście badań prowadzonych nad islamem w tym obszarze. Languages of Belonging. Islam, Regional Identity and the Making of Kashmir jest wyjątkowo aktualną publikacją, biorąc pod uwagę współczesne wydarzenia w indyjskim Kaszmirze skupiające się wokół obrony własnej tożsamości.

\section{BIBLIOGRAFIA}

Garlicki, J., Noga-Bogomilski, A. 2004. Kultura polityczna w społeczeństwie demokratycznym, Instytut Nauk Politycznych Uniwersytetu Warszawskiego, Warszawa.

Kieniewicz, J. 1980. Historia Indii, Zakład Narodowy im. Ossolińskich, Warszawa.

Syliwoniuk, A. 2016. Więzi społeczne w kulturze politycznej: przypadek Maroka na tle innych państw arabskich, Wydawnictwo Elipsa, Warszawa.

Wnuk-Lipiński, E. 2008. Socjologia życia publicznego, Wydawnictwo Naukowe Scholar, Warszawa.

Załęski, P. 2011. Kultura polityczna więzi w Azji Centralnej (przypadek Kirgistanu na tle państw regionu), Wydawnictwo ASPRA, Warszawa.

Zutshi, C. 2015. Languages of Belonging: Islam, Regional Identity, and the Making of Kashmir, Permanent Black, New Delhi. 